\title{
GENETIC PARAMETERS FOR BODY WEIGHT OF EGYPTAIN FARAFRA LAMBS WITH RANDOM REGRESSION MODEL
}

\author{
E. Mousa ${ }^{1}$, Mona A. Osman ${ }^{2}$ and U. M. EL-Saied ${ }^{2}$ \\ 1- Department of Animal Production, Faculty of Agriculture, Assuit University, \\ Assuit, Egypt, 2- Animal production Research Institute, Ministry of Agriculture \\ and Land Reclamation, Dokki, Giza, Egypt
}

\section{SUMMARY}

Genetic parameters of body weight were estimated for a total of 13996 records of Farafra lambs. Data were collected during the years 1991-2001 from a single experimental sheep flock raised under accelerated lambing system and belonging to Animal Production Research Institute (, El-Menia Governorate, Egypt).

Lamb body weights were measured at birth (wt $\left.t_{0}\right)$ and monthly thereafter up to 12 month of age $\left(w t_{12}\right)$. Lamb weights were analyzed using random regression model $(R R M)$ to estimate (co)variance components. Fixed effects included in the mixed model were year-season of birth, age of dam at lambing, type of birth and sex of lamb.

Heritability estimates were $0.36,0.37,0.37,0.33,0.32,0.32,0.32,0.34,0.35$, $0.35,0.35,0.33$ and 0.30 , respectively. The corresponding permanent environmental effects were 0.59, 0.55, 0.53, 0.59, 0.63, 0.64, 0.64, 0.63, 0.63, 0.63, 0.63, 0.65 and 0.69 , respectively.

Genetic correlations between each pair of weight records varied from -0.27 to 1.00. Phenotypic correlation ranged from -0.35 to 0.97 .

In view of the obtained results, genetic selection to improve body weight in Farafra lambs is expected to have good response from birth to 8 weeks of age.

Keywords: Genetic parameters, body weight, Farafra lambs, random regression

\section{INTRODUCTION}

Genetic improvement in livestock species depends on the identification of animals capable of transmitting the desirable characteristics to their offspring. Genetic characterization of sheep breeds with respect to their pattern of growth seems important for sheep breeders. Moreover, Farafra sheep breed is considered to be one of the local genetic resources in Egypt that yet did not receive due attention.

Studying growth performance through body weights with more precise techniques is most needed. Since most growth traits appear to be genetically correlated, a change in one trait could result in a change in the others. Therefore, knowledge of genetic and phenotypic relationships among these traits is necessary in the formulation of effective selection programs. Estimation of (co) variance components for Farafra lamb body weights and phenotypic and genetic correlations among body weights at various ages and of growth parameters form the basis of this study.

Issued by The Egyptian Society of Animal Production 
Estimates of genetic parameters are most often estimated using REML procedure through different models. Models that deal with repeated measurements have been often used in animal production. In dairy cattle, the analysis of multiple lactation records is often considered using 'repeatability model'. The typical feature of such a model from the genetics point of view is that repeated records are thought of as expression of the same trait, that is, the genetic correlation between repeated lactation is considered to be equal to unity (Van der Werf and Schaeffer, 1997). Random regression models (RRM) have been suggested for genetic analysis because of its ability to model a separate growth or lactation curve for every animal in a more precise way. Van der Werf and Schaeffer (1997) preferred the RRM because it takes into account the continuous nature of measuring and uses information on relatives in gaining accuracy. Kirkpatrick et al. (1990); Mekkawy (2000) and Alnajjar (2001) described in details the algorithm of the RRM.

Jamrozik and Schaeffer (1997) and Jamrozik et al. (1997) clarified the advantages to use RRM in genetic evaluation. Using the RRM, the production curve for an individual animal could be viewed as two sets of regressions on time. Fixed regressions for all individuals belonging to the same subclass of fixed effects describe the general shape for that individual, and the random regression for an individual describe the deviations from the fixed regression, which allows the individual to have differently shaped curves. Most of applications in RRM have been on repeated records in dairy cattle. Little is known on weight as a repeated trait using RRM.

The objective of this study was to estimate genetic parameters for body weight trait measured over time in Farafra lambs using the RRM.

\section{MATERIALS AND METHODS}

\section{Data}

Thirteen weights were considered from birth to 12 month of age on 1223 lamb progeny of 93 sires and 333 dams. Data were collected from the sheep flock of Mallawi Experimental Station in south Egypt belonging to Animal Production Research Institute, Ministry of Agriculture and Land Reclamation (El-Menia Governorate, Egypt) between 1991 and 2001.

\section{Management of the flock}

Farafra sheep are dominant in El-Farafra Oasis of the New Valley. They were introduced to Mallawi Research Station in 1990. Farafra sheep involved in the present study are characterized by white color and occasional brown head, fat tail, which looks like a funnel with both sexes being hornless. Occasionally rams carry scurs of small size and ears also of small size (Mousa et al. 1997).

The flock was allowed to graze on Egyptian clover pasture (Trifolium Alexandrium) during the months from December to May. However, in summer and autumn the flock grazed crop stubbles and green fodder, if available, in addition to concentrate mixture, clover hay and rice straw. Supplementary concentrate feeding of about $1 / 4 \mathrm{~kg} /$ head was offered two weeks prior to the mating season for flushing and also during the last two to four weeks of pregnancy and first weeks of lactation. Sheep were allowed to drink twice or three times daily. Animals were sheared twice a year, in March and September. Ewes and rams were first mated at approximately 1.5 
years of age. During the mating season the ewes were randomly divided into mating groups of 30 to 35 ewes. Each group was joined with a fertile ram for a period of 3545 days. In case of ram disability, a replacement with another fertile one took place one week after the removal.

Mating every eight months in May, January and September was practiced and therefore lambs were dropped in October, June and February. Lambs were kept with their dams up to weaning (eight weeks age) and weighed at monthly intervals until 12 months of age.

Four fixed effects were included in the mixed model, year-season of birth (31 levels resulting from 11 years and 3 lambing seasons per year); age of dam at lambing (four levels: 2, 3, 4 and >4 years old); type of birth (four levels: 1, 2, 3 and 4 lamb per ewe) and gender of lamb (two levels: male or female).

\section{Statistical Analysis}

Many mathematical models of both linear and non linear functions have been used to describe growth data in various species such as Brody (Brody, 1945), Exponential (Brody, 1945), Von Bertalanffy (Bertalanffy, 1957), Simple and Multiple Regression (Rao, 1958 and Sprent, 1967), Richards (Richards, 1959), Logistic (Nelder, 1961), Gompertz (Eisen et al., 1969) and Parabola equation (Mousa, 1989). A preliminary analysis of the data used in this study, showed that the Parabola function is the preferable one over the others. This conclusion was based on the coefficient of determination, the computational ease and the relatively simple biological interpretation of the estimated parameters. The relationship between weight and age is curvilinear. Parabola equation with three covariate terms was fitted for each animal according to the following equation:

$\mathrm{y}_{\mathrm{t}}=\beta_{\mathrm{o}}+\beta_{1} \mathrm{t}+\beta_{2} \mathrm{t}^{2}+\mathrm{e}_{\mathrm{t}}$;

where:

$\mathrm{y}_{\mathrm{t}} \quad$ is the weight of lamb at time $\mathrm{t}, \mathrm{kg}$;

$\beta_{\mathrm{o}} \quad$ is the initial body weight at age $=0$;

$\beta_{1} \quad$ is the partial linear regression coefficient of body weight on age $t$;

$\beta_{2} \quad$ is the partial quadratic regression coefficient of body weight on $\mathrm{t}^{2}$;

$\mathrm{t} \quad$ is the age in days; and

$\mathrm{e}_{\mathrm{t}} \quad$ is the error term associated with each weight.

The first derivative of $\hat{y}_{t}$ (the predicted value of $y_{t}$ with respect to age " $t$ ") measures the change of weight over time, known as growth rate (Brody, 1945) as can be seen in the following equation:

$$
\begin{aligned}
\delta \mathrm{y} / \delta \mathrm{t} & =\delta\left(\beta_{\mathrm{o}}+\beta_{1} \mathrm{t}+\beta_{2} \mathrm{t}^{2}\right) / \delta \mathrm{t}, \\
& =\beta_{1}+2 \beta_{2} \mathrm{t}
\end{aligned}
$$

This means that the parameter $\beta_{1}$ reflects the average growth rate, while $\beta_{\mathrm{o}}$ reflects the birth weight and $\beta_{2}$ is the decrease in daily gain over time (Mousa, 1989).

A model that includes both fixed and random linear and quadratic regressions on Legendre polynomial function following the work of Kirkpatrick et al. (1990) was employed to analyze 13996 monthly body weight records of Farafra lambs. Weight traits were analyzed using a random regression animal model for each of the 13 trajectory weight traits including year-season of lambing, age of dam at lambing, type of birth and sex of lamb as fixed regressions on Legendre polynomial function. Random effects were the additive genetic effect of the individual, the permanent 
environmental effects on the individual (random regression) and residual effects for overall regression model associated with each animal. The random regression model (RRM) was as follows:

$\mathrm{Y}=\mathrm{Xb}+\mathrm{Z1a}+\mathrm{Z} 1 \mathrm{p}+\mathrm{Z} 2 \mathrm{e}+\varepsilon$;

where:

$\mathrm{Y}=$ observation vector of weight of lamb;

$\mathrm{b}=$ vector of fixed effects including fixed regressions;

$\mathrm{a}=$ vector of animal additive genetic effects for random regression;

$\mathrm{p}=$ vector of permanent environmental effects for random regression;

$\mathrm{e}=$ vector of residual effects for random regressions;

$\mathrm{X}$ = incidence matrix for fixed effects;

$Z_{1} \quad$ incidence matrix for animal and permanent environmental effects;

$\mathrm{Z}_{2} \quad=$ matrix of covariates for each observation; and

$\varepsilon \quad=$ vector of random residual effect for the overall regression model.

Estimates of genetic parameters and covariance function for additive genetic and permanent environmental effects were obtained using DFREML program, version $3 \alpha$ of Meyer (1998).

\section{RESULTS AND DISCUSSION}

Weights at birth $\left(\mathrm{wt}_{0}\right)$ and at weaning ( $\left.\mathrm{wt}_{2}\right)$ have been chosen, both being traits of practical importance, to calculate averages and perform an analysis of variance. Average weights at birth and at weaning $( \pm \mathrm{SE})$ were $3.36 \pm 0.65 \mathrm{~kg}$ and $12.69 \pm 2.38$ $\mathrm{kg}$, respectively. Results of analysis of variance demonstrated that year-season of lambing and type of birth (single or multiple) had a significant effect $(P<0.0001)$ on weight at both birth and weaning. However, gender of lamb had a significant effect $(P<0.0001)$ on birth weight only. Age of dam at lambing had highly significant effect $(P<0.0001)$ on weaning weight only.

Covariance matrix of additive genetic and permanent environmental effects for the parabola equation is presented in table 1. These covariance are used to estimate genetic parameters for body weight at any point on the trajectory (age of lamb), which ranged in this study from birth to 360 days of age (12 months).

Table 1. Estimates of (co)variance for additive genetic (a) and permanent environmental $(\mathrm{p})$ random regression coefficients for body weigh traits of Farafra lambs

\begin{tabular}{ccccccccc}
\hline & $\mathrm{a} 0$ & $\mathrm{a} 1$ & $\mathrm{a} 1$ & & & $\mathrm{p} 0$ & $\mathrm{p} 1$ & $\mathrm{p} 2$ \\
\hline $\mathrm{a} 0$ & 4.12 & & & & $\mathrm{p} 0$ & 8.08 & & \\
$\mathrm{a} 1$ & 2.51 & 3.28 & & & $\mathrm{p} 1$ & 3.97 & 6.78 & \\
$\mathrm{a} 1$ & -2.24 & -1.14 & 2.61 & & $\mathrm{p} 2$ & -6.40 & -.19 & 10.10 \\
\hline
\end{tabular}

$\mathrm{a}_{0}=$ estimate of additive genetic effect of the initial body weight (birth weight, $\mathrm{kg}$ ).

$\mathrm{a}_{1}$ = estimate of additive genetic effect of partial linear regression of live weight, $\mathrm{kg}$, on age.

$\mathrm{a}_{2}$ = estimate of additive genetic effect of partial quadratic regression of live weight on age.

$\mathrm{p}_{0}=$ estimate of permanent environmental effect of the initial body weight (birth weight, kg). 
$\mathrm{p}_{1}$ = estimate of permanent environmental effect of partial linear regression of live weight on age.

$\mathrm{p}_{2}$ = estimate of permanent environmental effect of partial quadratic regression of live weight on age.

Heritability $\left(\mathrm{h}^{2}\right)$ estimates of the studied traits are given in the diagonal of table 2 and graphically presented in Figure 1. Many authors reported similar estimates as those reported in this work (Chopra and Acharya, 1971; Ercanbrack and Price, 1972, 1977; Olson et al., 1976; Aboul-Naga and Afifi, 1982; Chaudhary and Shah, 1985 and Kumar and Raheja, 1993). Little differences were observed between heritabilities estimates with advancing age from birth weight (0.36) to weight at 12 months $(0.30)$. The minimum estimate of heritability was at 12 months $(0.30)$ followed by $\mathrm{wt}_{4}$ to $\mathrm{wt}_{6}$ (0.0.32), while the maximum estimate was found at the first and second month $(0.37)$ and at birth (0.36). Strable and Misztal (1999) stated that swings of heritability estimates could be an artifact of using single trait random regression. In general, heritabilities estimated in this study were moderate. The average of these estimates was 0.33 and estimates were highest between birth weight and weight at 8 weeks of age (from 0.36 to 0.37 ) indicating a high-expected response to selection for the trait in general and especially in the mentioned period.

Estimates of genetic and phenotypic correlations between body weights are presented in table 2. With the exception of " $\mathrm{wt}_{0}{ }^{\prime}$ and " $\mathrm{wt}_{1}$ " genetic correlations ranged from 0.18 to 1.00 and are positive between each pair of weight records till "wt ${ }_{12}$ ". Correlations were very high between adjacent weights and tended to decrease with increasing the interval between weights. Such results are expected may be due to an autocorrelation among the error terms associated with the measurements. Mavrogenis et al., (1980) and Mansour (1982) stated the same reason for similar results. The high and positive correlations obtained in this study suggest that a high correlated response is expected when selection is made to improve weight trait in any age within the above-mentioned range.

Unexpected negative genetic correlations were found between birth weight and subsequent weights from "wt "up to "wt ${ }_{12}$ ". Chopra and Acharya (1971), Olson et al. (1976), Aboul-Naga and Afifi (1982), Chaudhary and Shah (1985) and Kumar and Raheja (1993) found negative estimates for genetic correlations as obtained in this study. It is important to point out that genetic correlations are subject to varying degrees of error than heritabilies for the same amount of data (Bowman, 1968). Brown (1972) added that difference in genetic correlation is not always obvious. The missing records in more than one of the concerned weights in this study could lead to inaccurate genetic correlation in most cases. However, the estimates of genetic correlations between birth weight $\left(\mathrm{wt}_{0}\right)$ and subsequent weights should be taken with caution in view of the lack of studies on Farafra sheep and on RRM as a more recently used technique for weight traits. In general, phenotypic correlations followed the genetic ones either in the relative magnitude or in the direction. The negative phenotypic correlation between birth weight and subsequent weights from " $\mathrm{wt}_{4}$ " up to "wt ${ }_{12}$ " supported the hypothesis that lambs with lighter body weights at birth tend to grow faster during postnatal interval. This concept of compensatory gain is frequently reported in the literature (Ercanbrack and Price, 1972, 1977; Olson et al., 1976; Aboul-Naga and Afifi, 1982). 
Mousa et al. 
Residual and permanent environmental variances of the studied weights are presented in tables 3 and 4, respectively.

Table 3. Residual variances $\left({ }_{e}^{2}\right)$ of weight records from birth $\left(\mathrm{Wt}_{0}\right)$ to 12 -month age $\left(\mathbf{W t}_{12}\right)$ for Farafra lambs

\begin{tabular}{cccccccc}
\hline Trait & ${ }_{\mathrm{e}}$ & Trait & ${ }_{\mathrm{e}}$ & Trait & ${ }_{\mathrm{e}}$ & Trait & ${ }_{\mathrm{e}}^{2}$ \\
\hline $\mathrm{Wt}_{0}$ & .60 & $\mathrm{Wt}_{4}$ & 3.37 & $\mathrm{Wt}_{8}$ & 4.30 & $\mathrm{Wt}_{12}$ & 3.66 \\
$\mathrm{Wt}_{1}$ & 1.49 & $\mathrm{Wt}_{5}$ & 3.37 & $\mathrm{Wt}_{9}$ & 4.27 & & \\
$\mathrm{Wt}_{2}$ & 2.19 & $\mathrm{Wt}_{6}$ & 4.04 & $\mathrm{Wt}_{10}$ & 4.14 & & \\
$\mathrm{Wt}_{3}$ & 2.83 & $\mathrm{Wt}_{7}$ & 4.22 & $\mathrm{Wt}_{11}$ & 3.89 & & \\
\hline
\end{tabular}

Permanent environmental variance as proportion of phenotypic variance is presented in table 4 and Figure 2. The proportions ranged from 0.53 to 0.69 . Through the estimates, three stages can be noticed (up and down). Firstly, estimates decreased from birth weight $\left(\mathrm{wt}_{0}\right)$ to " $\mathrm{wt}_{2}{ }^{\prime}$, secondly, increased from " $\mathrm{wt}_{3}$ " to " $\mathrm{wt}_{6}$ " and thirdly, decreased again from " $\mathrm{wt}_{7}$ " to " $\mathrm{wt}_{10}$ " and decreased thereafter to the end of weights. Strable and Misztal (1999) stated that single trait random regression may cause large fluctuations in proportion estimates. This could be the case for the current work. Also, Van der Werf et al. (1998) added that one function is not sufficient to describe all components of the model correctly, therefore the permanent proportions have unsteady pattern, the procedure can not handle function for each component.

\section{CONCLUSION}

Heritability estimates were highest for weights from the birth to weight at 8 weeks of age and therefore genetic selection for body-weigh of Farafra lambs is expected to have the highest selection response in this period. Moreover, genetic correlation was very high and positive between pairs of weight observations from $\mathrm{wt}_{3}$ to $\mathrm{wt}_{12}$ indicating a high expected correlated response to selection among these weights. However, genetic correlations should be taken with caution, especially correlation between " $\mathrm{wt}_{0}$ " with the rest of weight traits. Phenotypic correlations followed the genetic ones in the relative magnitude and direction.

\section{ACKNOWLEDGMENT}

The authors are grateful to Prof. Dr. E.S.E. Galal for his helpful comments and constructive criticism of the work. 
Mousa et al. 


\section{REFRERENCES}

Aboul-Naga, A.M. and E.A. Afifi, 1982. Genetic and phenotypic parameters of lamb performance traits in Ossimi, Rahmani and Barki Local sheep. $6^{\text {th }}$ Int.Con.Animal. Prod., Zagazig Univ., 1: 272-284.

Alnajjar, Kh.A., 2001. A study on animal genetic evaluation in dairy cattle. Ph.D. Thesis Animal Production Department, Faculty of Agriculture, Ain Shams University, Egypt.

Bertalanffy, L.V., 1957. Quantitative laws in metabolism and growth. Quart. Rev. Biol. 32: 217-231.

Bowman, J.C., 1968. Genetic variation of body weight in sheep. "Growth and development of mammals" by G.A. Loge and G. Elaming, Academy Press. London.

Brody, S. 1945. Bioenergetic and Growth. Rheinhold Pub. Corp., New York.

Brown, J.E., C.J. Brown and W.T. Butts, 1972. A discussion of genetic aspects of weight, mature weight and rate of maturing in Hereford and Angus cattle. J. Anim. Sci. 34:525-537.

Chopra, S.C. and R.M. Acharya, 1971. Genetic and phenotypic parameters of body weight in Bikaneri sheep (Magrastrain). Animal Production. 13:343-348.

Chuaudhary, M.Z. and S.K. Shah, 1985. Heritability and correlations of birth weight, weaning weight and 12 month weight in Lohi Awassi, Hissardale and Kalchi sheep. Pakistan Veterinary Journal. 5:67-71.

Eisen, B., J. Lang and J.E. Legates, 1969. Comparison of growth functions within and between lines of mice selected for large and small body weight. Theoretical and Applied Genetics. 39:251-260.

Ercanbrack, S.K. and D.A. Price, 1972. Selection for weight and rate of gain in noninbred lambs. J. Anim. Sci. No 5. 34:713-725.

Ercanbrack, S.K. and D.A. Price, 1977. Selection for weight and rate of gain in inbred lambs. J. Anim. Sci. No 4. 44:532-540.

Jamrozik, J., L.R. Schaeffer and J.C.M. Dekkers, 1997. Genetic evaluation of dairy cattle using test day yields and random regression model. J. Dairy Sci. 80:12171226.

Jamrozik, J. and L.R. Schaeffer, 1997. Estimates of genetic parameters for a test day model with random regression for yield traits of first lactation Holsteins. J. Dairy Sci. 80:762-770.

Jamrozik, J., L.R. Schaeffer and F. Grigola, 1998. Genetic parameters for production traits and somatic cell score of Canadian Holsteins with multiple trait random regression model. Proc. $6^{\text {th }}$ World Congr. Genet. Appl. Livest. Prod. January 1116. Armidale, New South Wales Australia. 23:303-306.

Kirkpatrick, M., D. Lofsvold, and M. Bulmer, 1990. Analysis of the inheritance, selection and evaluation of growth trajectories. Genetics. 124:979-993.

Kumar, N. and K.L. Raheja, 1993. Genetic and phenotypic parameters of growth and reproduction traits in UAS strain of sheep estimated by multitrait animal model. Indian Journal of Animal Sciences. No 9. 63:978-983.

Mansour, H., 1982. Analysis of covariance structures in repeated measures designs with reference to estimation repeatability. Ph.D. Thesis, University of Wisconsin, Madison, U.S.A. 
Mavrogenis, A.P., A. Louca and O.W. Robison, 1980. Estimates of genetic parameters for pre-weaning and post-weaning growth traits of Chios lambs. Animal Prod. 30:271-276.

Mekkawy, W.A.I., 2000. Estimation of genetic parameters for growth performance of Zaraibi Goats. M.Sc. Thesis. Animal Production Department, Faculty of Agriculture, Ain Shams University, Egypt.

Meyer, K., 1998. DFREML program, User's manual. http:agbu.une.edu.au / kmeyer/dfreml.html.

Mousa, E., 1989. Phenotypic and genetic variation in lambs growth. M.Sc. Thesis. Faculty of Agriculture. Assiut University. Assiut, Egypt.

Mousa, M.T., M.N. Abd El- Ati, F.F.El-Hommosi and H.A.M.Hamdom, 1997. The yield and composition of milk from Egyptian Oasis (Farafra) and Chios sheep. Proceeding of the first Scientific Conference of Agricultural Sciences Faculty of Agric .Assiut Univ., Assiut, December 13-14, 1997-Vol. II

Nelder, J.A., 1961. The fitting of generalization of the logistic curve. Biometrics. 17: 89-110.

Olson, L.W., G.H. Dickerson and H.A. Glimp, 1976. Selection criteria for intensive market lamb production: Growth traits. J. Anim. Sci. 43:78-89.

Rao, C.R. 1958. Some statistical methods for comparison of growth curves. Biometrics 14:1-17.

Richards, F.J., 1959. A flexible growth function for empirical use. Journal of Experimental Botany. No 29. 10:290-300.

Sprent, P., 1967. Estimation of mean growth curves for groups of organisms. J. Theoret. Biol. 17:159-173.

Strable, T., and I. Misztal, 1999. Genetic parameters for first and second milk yields of Polish Black and white cattle with random regression test-day models. J. Dairy Sci. 82:2805-2810.

Van der Werf, J.H.J., and L.R. Schaeffer, 1997. Random Regression in Animal Breeding, Course note, CGIL Guelph, June 25-28, 1997, pp: 59.

Van der Werf, J.H.J., M. E. Godard and K. Meyer, 1998. The use of covariance functions and random regressions for genetic evaluation of milk production based on test day records. J. Dairy Sci. 81:3300-3308. 
المقاييس الوراثية لوزن الجسم في حملان الفرافرة المصرية بإستخدام نموذج الانحدار العثوائي

عماد موسى1، منى عبد الظاهر عثمان، أسامة محمد السعيد²

1- قسم الإنتاج الحيواني، كلية الزراعة ، جامعة أسيوط، أسيوط - مصر، 2-معطه بحوث الإنتاج الحيوانس، وزارة الززراعة وإستصلاح الأراضى، الدقى، الجبيزة - مصر.

قدرت المعايير الوراثية لإجمالي 13996 سجل وزن لحملان الفرافرة. جمعت البيانات بين عامي 1991

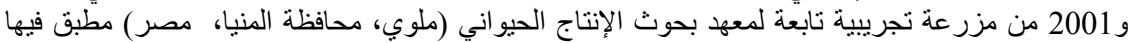
نظام إنتاج الأغنام المنسارع (accelerated).

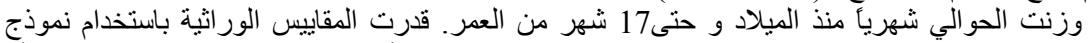

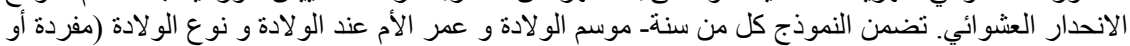

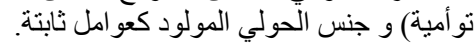

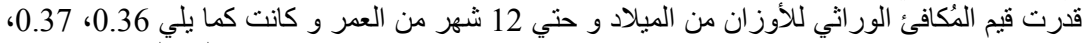

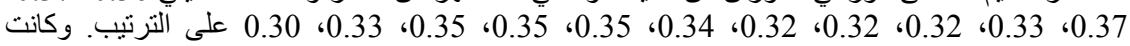

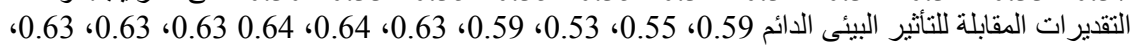

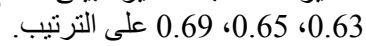

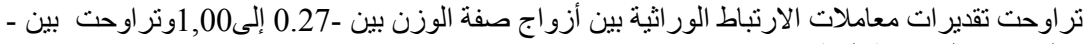
0.35

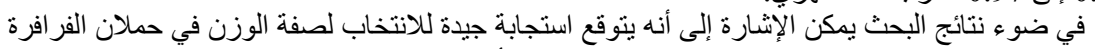
بصفة عامة و خاصة في المرحلة العمرية من الميلاد وحتى 8 أسابيع من العمر. 
Mousa et al. 
Table 2. Heritability (in the diagonal) and estimates of genetic (upper diagonal) and phenotypic (lower diagonal) correlations among body weight records from birth $\left(\mathrm{Wt}_{0}\right)$ to 12 -month age $\left(\mathrm{Wt}_{12}\right)$ for Farafra lambs

\begin{tabular}{cccccccccccccc}
\hline & $\mathrm{Wt}_{0}$ & $\mathrm{Wt}_{1}$ & $\mathrm{Wt}_{2}$ & $\mathrm{Wt}_{3}$ & $\mathrm{Wt}_{4}$ & $\mathrm{Wt}_{5}$ & $\mathrm{Wt}_{6}$ & $\mathrm{Wt}_{7}$ & $\mathrm{Wt}_{8}$ & $\mathrm{Wt}_{9}$ & $\mathrm{Wt}_{10}$ & $\mathrm{Wt}_{11}$ & $\mathrm{Wt}_{12}$ \\
$\mathrm{Wt}_{0}$ & $\mathbf{0 . 3 6}$ & 0.98 & 0.78 & 0.44 & 0.14 & -0.05 & -0.16 & -0.23 & -0.27 & -0.29 & -0.28 & -0.26 & -0.22 \\
$\mathrm{Wt}_{1}$ & 0.91 & $\mathbf{0 . 3 7}$ & 0.90 & 0.61 & 0.35 & 0.16 & 0.05 & -0.03 & -0.08 & -0.11 & -0.12 & -0.12 & -0.10 \\
$\mathrm{Wt}_{2}$ & 0.64 & 0.78 & $\mathbf{0 . 3 7}$ & 0.90 & 0.73 & 0.58 & 0.48 & 0.40 & 0.35 & 0.30 & 0.26 & 0.22 & 0.18 \\
$\mathrm{Wt}_{3}$ & 0.25 & 0.46 & 0.80 & $\mathbf{0 . 3 3}$ & 0.95 & 0.88 & 0.81 & 0.75 & 0.70 & 0.65 & 0.59 & 0.52 & 0.43 \\
$\mathrm{Wt}_{4}$ & -0.03 & 0.21 & 0.65 & 0.89 & $\mathbf{0 . 3 2}$ & 0.98 & 0.95 & 0.91 & 0.87 & 0.82 & 0.77 & 0.69 & 0.60 \\
$\mathrm{Wt}_{5}$ & -0.18 & 0.05 & 0.61 & 0.83 & 0.94 & $\mathbf{0 . 3 2}$ & 0.99 & 0.97 & 0.94 & 0.88 & 0.86 & 0.78 & 0.69 \\
$\mathrm{Wt}_{6}$ & -0.28 & -0.05 & 0.44 & 0.77 & 0.91 & 0.95 & $\mathbf{0 . 3 2}$ & 0.99 & 0.97 & 0.95 & 0.91 & 0.84 & 0.75 \\
$\mathrm{Wt}_{7}$ & -0.35 & -0.11 & 0.36 & 0.72 & 0.87 & 0.93 & 0.96 & $\mathbf{0 . 3 4}$ & 1.00 & 0.98 & 0.94 & 0.89 & 0.81 \\
$\mathrm{Wt}_{8}$ & -0.35 & -0.15 & 0.30 & 0.65 & 0.82 & 0.90 & 0.94 & 0.97 & $\mathbf{0 . 3 5}$ & 0.99 & 0.97 & 0.93 & 0.86 \\
$\mathrm{Wt}_{9}$ & -0.35 & -0.17 & 0.24 & 0.58 & 0.75 & 0.83 & 0.89 & 0.93 & 0.96 & $\mathbf{0 . 3 5}$ & 0.99 & 0.97 & 0.91 \\
$\mathrm{Wt}_{10}$ & -0.31 & -0.17 & 0.18 & 0.48 & 0.64 & 0.74 & 0.81 & 0.87 & 0.92 & 0.96 & $\mathbf{0 . 3 5}$ & 0.99 & 0.96 \\
$\mathrm{Wt}_{11}$ & -0.26 & -0.15 & 0.06 & 0.36 & 0.51 & 0.61 & 0.67 & 0.76 & 0.84 & 0.91 & 0.96 & $\mathbf{0 . 3 3}$ & 0.99 \\
$\mathrm{Wt}_{12}$ & -0.18 & -0.12 & 0.05 & 0.23 & 0.35 & 0.45 & 0.53 & 0.63 & 0.72 & 0.82 & 0.90 & 0.96 & $\mathbf{0 . 3 0}$ \\
\hline
\end{tabular}


Table 4. Permanent environmental variances as a proportion of total phenotypic variances are (on the diagonal) and the correlations between these effects (above diagonal) from birth $\left(\mathrm{Wt}_{0}\right)$ to 12-month age $\left(\mathrm{Wt}_{12}\right)$ for Farafra lambs

\begin{tabular}{|c|c|c|c|c|c|c|c|c|c|c|c|c|c|}
\hline & $\mathrm{Wt}_{0}$ & $\mathrm{Wt}_{1}$ & $\mathrm{Wt}_{2}$ & $\mathrm{Wt}_{3}$ & $\mathrm{Wt}_{4}$ & $\mathrm{Wt}_{5}$ & $\mathrm{Wt}_{6}$ & $\mathrm{Wt}_{7}$ & $\mathrm{Wt}_{8}$ & $\mathrm{Wt}_{9}$ & $\mathrm{Wt}_{10}$ & $\mathrm{Wt}_{11}$ & $\mathrm{Wt}_{12}$ \\
\hline $\mathrm{Wt}_{0}$ & 0.59 & 0.96 & 0.63 & 0.17 & -0.12 & -0.27 & -0.36 & -0.40 & -0.42 & -0.40 & -0.35 & -0.27 & -0.16 \\
\hline $\mathrm{Wt}_{1}$ & & 0.55 & 0.82 & 0.42 & 0.15 & -0.01 & -0.11 & -0.17 & -0.21 & -0.23 & -0.27 & -0.19 & -0.14 \\
\hline $\mathrm{Wt}_{2}$ & & & 0.53 & 0.87 & 0.69 & 0.56 & 0.46 & 0.38 & 0.31 & 0.23 & 0.15 & 0.07 & -0.01 \\
\hline $\mathrm{Wt}_{3}$ & & & & 0.59 & 0.96 & 0.89 & 0.83 & 0.76 & 0.69 & 0.59 & 0.49 & 0.30 & 0.14 \\
\hline $\mathrm{Wt}_{4}$ & & & & & 0.63 & 0.98 & 0.95 & 0.91 & 0.84 & 0.75 & 0.62 & 0.45 & 0.26 \\
\hline $\mathrm{Wt}_{5}$ & & & & & & 0.64 & 0.99 & 0.96 & 0.92 & 0.84 & 0.71 & 0.54 & 0.35 \\
\hline $\mathrm{Wt}_{6}$ & & & & & & & 0.64 & 0.99 & 0.96 & 0.90 & 0.79 & 0.63 & 0.45 \\
\hline $\mathrm{Wt}_{7}$ & & & & & & & & 0.63 & 0.99 & 0.95 & 0.86 & 0.73 & 0.56 \\
\hline $\mathrm{Wt}_{8}$ & & & & & & & & & 0.63 & 0.98 & 0.93 & 0.82 & 0.67 \\
\hline $\mathrm{Wt}_{9}$ & & & & & & & & & & 0.63 & 0.98 & 0.88 & 0.75 \\
\hline $\mathrm{Wt}_{10}$ & & & & & & & & & & & 0.63 & 0.98 & 0.90 \\
\hline $\mathrm{Wt}_{11}$ & & & & & & & & & & & & 0.65 & 0.98 \\
\hline $\mathrm{Wt}_{12}$ & & & & & & & & & & & & & 0.69 \\
\hline
\end{tabular}

Figure 1. Heritability estimates of body weight records from birth $\left(\mathrm{WT}_{0}\right)$ to 12 -month age $\left(\mathrm{Wt}_{12}\right)$ for Farafra lambs 


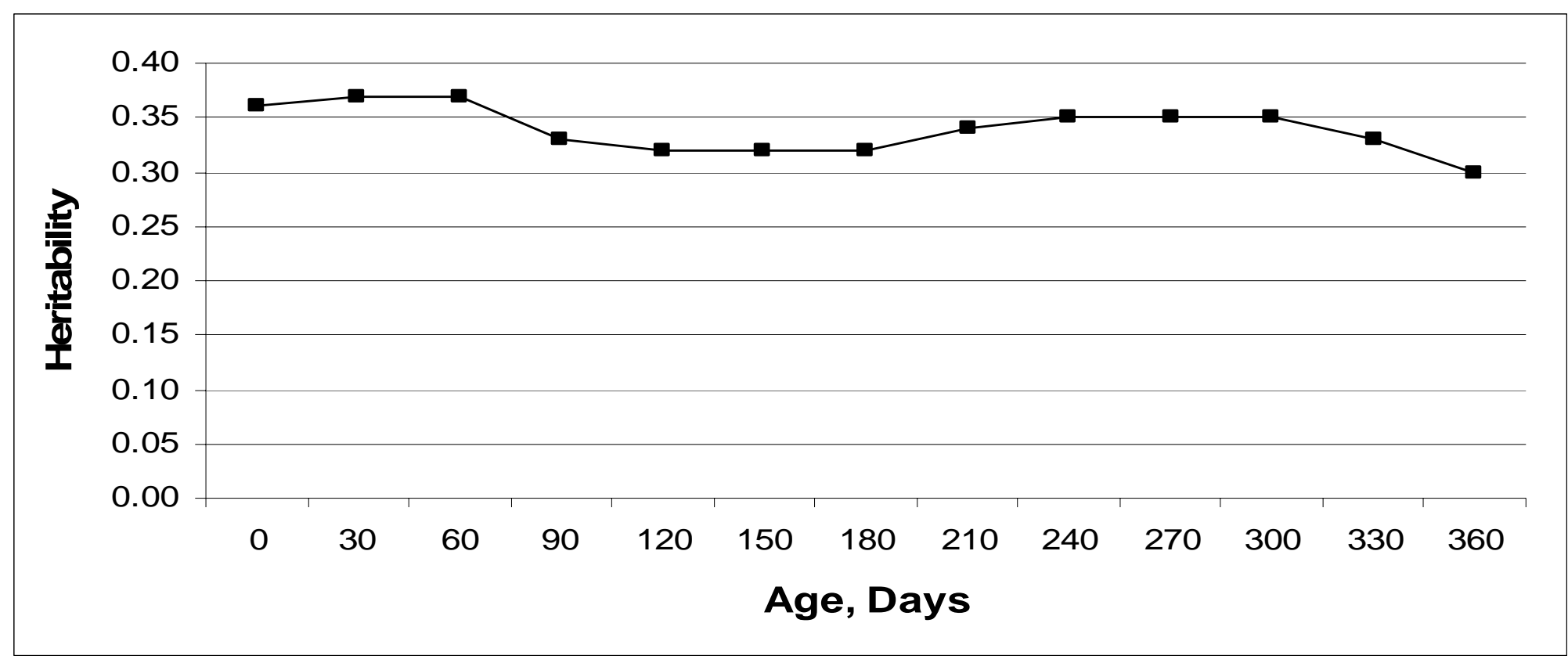




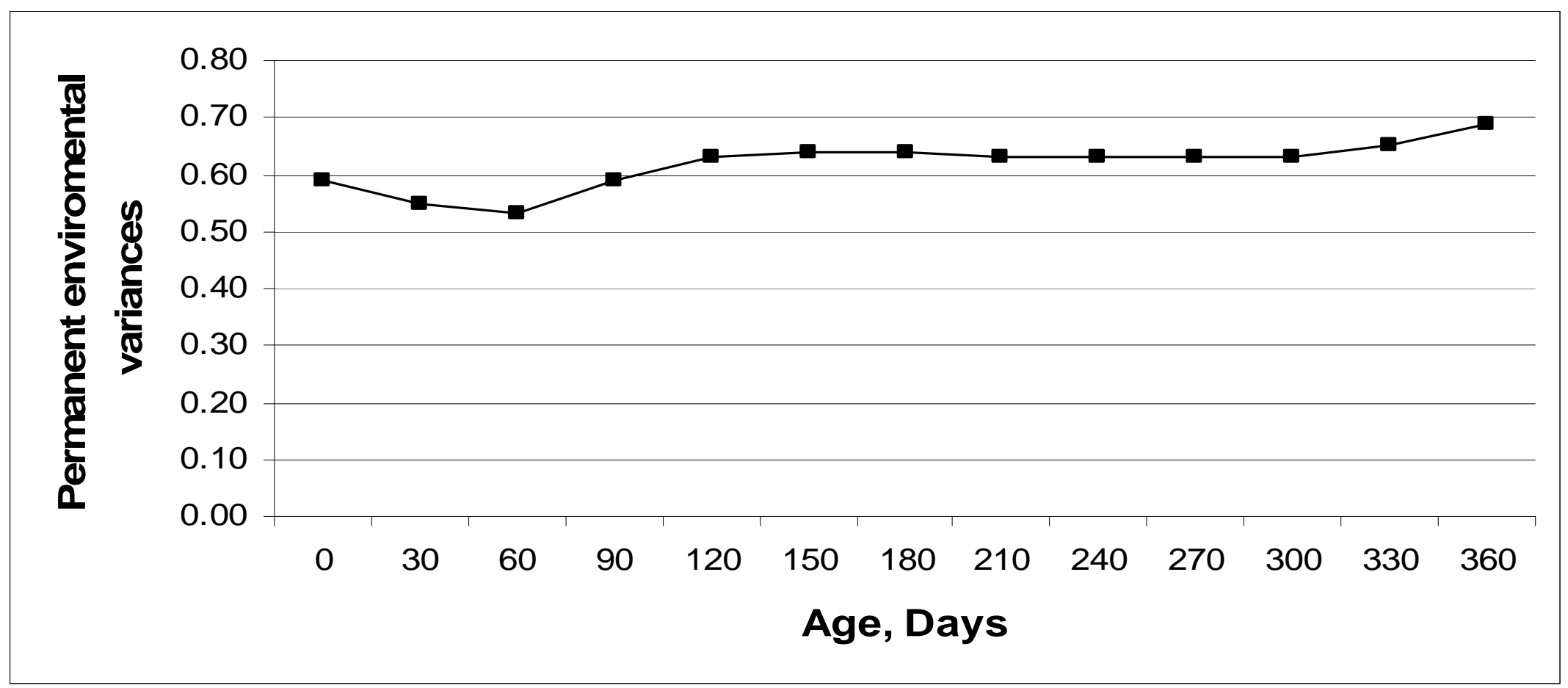

Figure 2. Permanent environmental variances as a proportion of total phenotypic variances from birth $\left(\mathrm{WT}_{0}\right)$ to 12 -month age $\left(\mathrm{Wt}_{12}\right)$ for Farafra lambs 
